\title{
Measuring ICT usage quality for information society building
}

\author{
Bjarne Rerup Schlichter ${ }^{\mathrm{a}, *}$, Lesya Danylchenko ${ }^{\mathrm{b}}$ \\ a Aarhus University, Business and Social Sciences, Department of Business Administration, IS Research Group, Bartholins Alle 10, 8000 Aarhus C, Denmark \\ b Ternopil National Economic University, Ukrainian Dutch Faculty, Department of Management and Marketing, Ukraine
}

\section{A R T I C L E I N F O}

Available online $\mathrm{xxxx}$

\section{Keywords:}

(Responsive) information society (building)

World Summit on the Information Society

Digital divide

(Actual levels of) ICT usage

e-readiness

Networked Readiness Index

ICT usage index

\begin{abstract}
A B S T R A C T
In 2003 the World Summit on Information Society made a call for measuring the state of Information Society (IS) building between countries. The purpose of the measuring was to assess and compare IS practices around the globe as well as share best practices. A number of measurement tools have since been developed, and a number of previously constructed tools have been employed to fulfil this goal. Even though many variations in terms of indicators have been employed, the construction of measurement tools is subject to certain limitations. One limitation is that they do not incorporate these indicators on the actual levels of Information and Communication Technology (ICT) usage off the country's stakeholders. This paper analyses the most currently used indices for measuring the state of Information Society building from the perspective of their constituent indicators. Based on the analysis, an alternative framework for IS measurement, addressing the important aspects of ICT usage quality, is developed based on data from the EU member states. By applying the framework on measuring of ICT usage quality at Romania, Cyprus and Estonia, the usefulness is tested positive, and the need to evaluate the actual levels of ICT usage for the purpose of better policy-making, while establishing an information society, is accentuated.
\end{abstract}

(c) 2013 Elsevier Inc. All rights reserved.

\section{Introduction}

The rapid proliferation of information and communication technologies across the globe in recent decades has fostered the rise of scientific and business interest in the problems of uneven information and communication technology (ICT) usage and information society (IS) building among and within the countries of the world. While it is widely accepted that ICT carries the potential of opening economic opportunities, promoting social and political changes in society, providing access to knowledge, creating stimulus and a field for best practice sharing in all areas of life, the actual processes of informatisation across the globe are quite asymmetrical. "Paradoxically, while the digital revolution has extended the frontiers of the global village, the vast majority of the world remains unhooked from this unfolding phenomenon" (WSIS, 2008). Even though Rodriguez and Wilson III argue that "The information revolution started in today's developed countries, so it makes sense that these countries have higher levels of technological attainment and higher use of ICT products", they further agree that, “...the magnitude of the differences is staggering" (Rodríguez \& Wilson, 2000, p.40). "Whole communities and countries may be excluded on account of historical, cultural and economic forces; the gulf between technology-rich and technology-poor countries and continents may be as stark as that between local communities and individuals" (McNair, 2000).

\footnotetext{
* Corresponding author. Tel.: +45 51339083.

E-mail address: brs@asb.dk (B.R. Schlichter).

URL: http://badm.au.dk/ (B.R. Schlichter).
}

Furthermore, proceeding on the basis that ICT does not operate in vacuum and, as any other technology advancement, is a result of wider developments, namely: scientific, innovation, social-economic, and institutional, uneven ICT diffusion across the world, reflects the disproportional global development. The lopsided pace of ICT adoption around the globe is, thus, an indication of a hardly noticeable, but very powerful process of social-economic dualisation at international and national levels. Moreover, there is a danger that unequal ICT expansion can result in reinforcing the existing social-economic inequalities: “...without internet access, which facilitates economic development and the enjoyment of a range of human rights, marginalized groups and developing States remain trapped in a disadvantaged situation, thereby perpetuating inequality both within and between States" (Rue, 2011, p. 17).

As stated by Sachs, "Today's world is divided not by ideology, but by technology" (Sachs, 2000). By internet technology, we would farther add, indeed, no other development in the ICT context have had such a breakthrough effect, as the creation of internet: "Unlike any other medium of communication, such as radio, television and printed publications based on one-way transmission of information, the internet represents a significant leap forward as an interactive medium. Indeed, with the advent of Web 2.0 services, or intermediary platforms that facilitate participatory information sharing and collaboration in the creation of content, individuals are no longer passive recipients, but also active publishers of information" (Rue, 2011, p. 6).

While recent reduction in costs of telecommunication and internet services contributed greatly to the increase of developing world connectivity rates, large differences between developed and developing 
countries still remain. According to a recent ITU report, average connectivity rates in developed countries are twice higher, than in the developing countries (ITU, 2012). The gap is even wider when looking at the uptake of advanced internet services, like fixed broadband. While mobile broadband penetration rates are growing in the developing countries, thus reflecting the spread of mobile internet services, fixed broadband services are still unaffordable in most developing states.

In view of this, public discourse on the topic of uneven ICT usage, initiated by scientists, policy makers and businessmen, moved to a global scale and was raised at the world's largest agenda-the United Nations. Two phases of the World Summit on the Information Society (WSIS), organised by the UN and ITU in Geneva (2003) and Tunis (2005), followed the aim of global discussion and development of ways to "ensure that everyone can benefit from the opportunities that ICTs can offer" (WSIS, 2003a).

The Summits 175 government delegates and assignees from various international organisations, ICT and media sector spokesmen, declared their "common desire and commitment to build a people-centred, inclusive and development-oriented Information Society", and acknowledged the challenge "to harness the potential of information and communication technology to promote the development goals of the Millennium Declaration" (WSIS, 2003a). The principles for the building of the IS adopted were transformed into a detailed Plan of Action (WSIS, 2003b), that set specific targets and timelines to advance the achievement of internationally-accepted goals and turn the vision of global IS into a reality.

Considerable attention during both phases of the Summit was devoted to the problem of international performance evaluation and benchmarking the progress towards an IS using comparable international statistics. The Geneva Plan of Action has clearly stated the importance of such evaluations: "appropriate indicators and benchmarking, including community connectivity indicators, should clarify the magnitude of the digital divide, in both its domestic and international dimensions, and keep it under regular assessment, and tracking global progress in the use of ICTs to achieve internationally agreed development goals, including those of the Millennium Declaration" (WSIS, 2003b). In this respect, the Tunis Agenda for the Information Society (WSIS, 2005) noted the launch of the Partnership on Measuring ICT for Development and, among others, its effort to develop a common set of core ICT indicators, which would also be used as a basis for two internationally calculated ICT indices-the ICT Opportunity Index and the Digital Opportunity Index.

The World Summit on the Information Society has generated keen interest, especially in the questions generated in its follow-up and evaluation. Besides the ICT Opportunity Index and Digital Opportunity Index, the Summit outcomes fostered the prolific development of various ICT-related measurement frameworks and tools by international organisations, scientists and policy-makers all over the world.

The significance of conducting such evaluations and comparisons cannot be underestimated. "Without some indication of how all elements of society are adapting to the installation and application of ICTs, there can be no way of understanding whether the shift towards an information society is actually taking place, or indeed, working in positive ways" (Hanafizadeh, Hanafizadeh, \& Khodabakhshi, 2009). Furthermore, international assessments and comparisons are valuable tools for policy-makers, allowing the tracking of their country's progress against others, distinguishing leading states in terms of IS building and bridging the digital divide, by examining their best practice, which can be further implemented at national levels.

However, the wide variety of measurement tools and frameworks available for application, creates difficulties in selecting the "best" or "right" measure and, thus, produces a number of questions: what indicators constitute the most widely used indices and what do they actually measure? How profound and realistic are these measurements? What actual conclusions can be made from these measurements?
The purpose of this paper is to present a framework that measures the actual levels of ICT usage, and hence guides policymakers in developing national strategies of responsive IS building.

As a foundation for our paper, we will review the most currently used indices for IS measurement from the position of their constituent indicators, then discuss them in terms of providing a realistic picture of the state of IS development. The paper will continue with an overview of data and description of the methodology used to develop an alternative tool. A presentation of the findings, limitations, discussion and future research directions will follow at the end.

\section{Background}

This section briefly reviews the relevant literature on IS, e-readiness, digital divide, and provides definitions and the authors' vision on the relations between the concepts. The second subsection analyses the constituent indicators of the most widely used indices for IS measurement, with the purpose of identifying their major focus and limitations.

\subsection{Information society, e-readiness and digital divide: definition of} concepts and their interrelations

The measuring of information societies is a "grand challenge" (Menou \& Taylor, 2006). Especially, when taking into account the abstractedness and generalised nature of the IS concept.

Based on the Geneva Declaration of Principles, a broad definition of the term can be developed: “... Information Society, where everyone can create, access, utilize and share information and knowledge, enabling individuals, communities and peoples to achieve their full potential in promoting their sustainable development and improving their quality of life" (WSIS, 2003a). The generally used generic definitions of the IS concept, e.g.: "An information society is a society in which the creation, distribution, diffusion, use, integration and manipulation of information is a significant economic, political, and cultural activity” (Wikipedia, 2011); “...a society in which information and knowledge will play critical roles in enabling the development of countries, communities and individuals" (Souter, 2010, p. 11), and "A new form of social existence in which the storage, production, flow, etc. of networked information plays the central role" (Karvalics, 2007), do not offer a clear understanding of the actual IS elements and their extreme points to be measured and compared. Thus, we must agree with Karvalics in this respect, “...it is not definitions that will reveal the genuine meaning of IS but comprehensive analyses extending to all sub-systems" (Karvalics, 2007). "The first challenge is to determine what it is that one is measuring. Is it information in society or an information society? Is it information or knowledge, or both, or ICT? Is it present state, or readiness, or potential, or outcomes?" (Menou \& Taylor, 2006).

The core list of ICT indicators (Partnership_on_MeasuringICT_for_Development, 2010) provided substance to the concept of the IS. The list includes 46 indicators in the following groups: infrastructure and access; access to and use of ICT by households and individuals; use of ICT by businesses; the ICT (producing) sector; international trade in ICT goods; ICT in education. The core list serves as a basis for tracking progress in terms of ICT usage in achieving internationally-agreed WSIS goals. Both the title of the core list, and its constituent indicators, clearly disclose the WSIS approach to IS measurement-by evaluating the levels of ICT integration in the society.

However, the level of IS development is not only characterised by the degree of technology integration, but also by the quality of national policies and regulatory practices that enable and promote the effective use of these technologies with the purpose of development, as well as the capacity of individuals, businesses and other national stakeholders to fully exploit the potential of ICT to improve the quality of life and achieve other goals (World_Economic_Forum_INSEAD, 2011). While the level of ICT adoption addresses the first part of the WSIS definition 


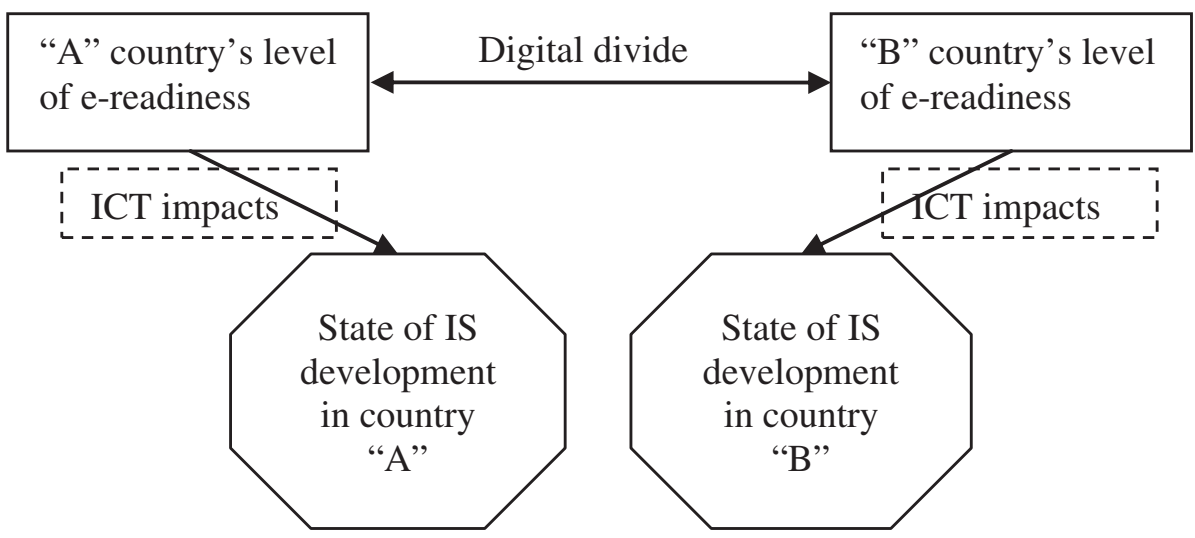

Fig. 1. Relations between information society, e-readiness and digital divide.

of IS, “...Information Society, where everyone can create, access, utilize and share information and knowledge...", it does not reflect the second important part of the definition, namely it does not disclose whether information and knowledge in this society is "...enabling individuals, communities and peoples to achieve their full potential in promoting their sustainable development and improving their quality of life" (WSIS, 2003a).

Various international organisations and scientists describe this enabling state of a society as "e-readiness" or "networked readiness". E-readiness definitions vary from:

- being largely comprehensive or generalised, e.g.: "Readiness is a degree to which a community is prepared to participate in the digital economy" (Bhatia, 2001)

- to more specific and focused: “... e-readiness as the ability to pursue value creation opportunities facilitated by the use of internet" (Choucri, Maugis, Madnick, \& Siegel, 2003).

Despite the variation in definitions and conceptual frameworks, developed by different authors (Bui, I. M. S., Jones, \& Naklada, 2002; Computer_Systems_Policy_Project, 2002; Harvard Center for International Development; McConnell_International, 2000; OECD, 1999; World_Economic_Forum_INSEAD, 2009), the degree of the relative e-readiness of a country is typically measured by a set of indicators, including both indicators on ICT adoption (infrastructure, access) and factors that mark the propensity for countries to exploit opportunities offered by ICT, namely social, economic, market, political, regulatory and other factors.

The "e-readiness approach" thus reflects two important stages on the way to IS measuring:

1. ICT adoption (infrastructure, access) and

2. ICT-enabling policies (appropriate economic, legal, regulatory, and so-

cial framework: 1) to support ICT access and usage; 2) to promote creation of value-adding from ICT usage, economically as well as socially.

Furthermore, e-readiness is crucial to the potential impact that ICT can have on social-economic development-the third stage in the progress towards IS. However, "The impact of ICT on the public sector is an issue that is still unsolved due to problems of measurement together with the lack of a clear theoretical framework" (European_Commission, 2009a, p. 16). "During and since WSIS there has been much concern about the lack of reliable and comparable data in developing countries concerning ICTs and the impact which they are having on societies. The statistics needed to measure this have not previously been collected in many countries, and rapid changes in technology, markets and societies make it difficult to keep track of changing information needs even where they are available" (Souter, 2010, p. 22). Indeed, "it is not easy to gauge whether or not ICT is beneficial for well-being and to the construction of social capital because these questions tend to be multi-faceted and to contain subjective elements... The availability of official statistics on time use and the role played by ICT technologies and applications should also be investigated in this context. In fact, several problems related to the measurement of the social impact of ICT is due to the limited measurement of ICT use" (European_Commission, 2009a). Thus, the lack of necessary statistics makes ICT impact measurement currently impractical, with e-readiness remaining an important condition to it.

When taking e-readiness as a measure, numerical value for the state of IS development of a certain country, the difference between such measures for several countries should therefore determine the level of digital divide between them (Fig. 1).

Digital divide, in this respect, goes beyond its generic definitions, e.g. "great disparities in opportunity to access the internet and the information and educational/business opportunities tied to this access ... between developed and developing countries" (Lu, 2001); "situations in which there is a marked gap in access to or use of ICT devices measured by, for example, the number of phone lines per inhabitant, or the number of internet users, or of mobile telephones in the population" (Campbell, 2001); 'the gap between individuals (citizens), groups of individuals, households, business establishments, geographic areas and countries with regard to access to and usage of information and communication technologies (ICTs), or the "Information Society"' (SIBIS, 2001); "wide division between those who have real access to information and communication technology (ICT) and are using it effectively, and those who don't" (Bhatia, 2001), and reflects the magnitude of differences between the countries in terms of the state of their IS development.

This section brings us to the conclusion that the numerous definitions of IS do not provide a clear understanding of this generalised concept and its elements. Terms like "a new form of social existence...", "...a society in which information and knowledge will play critical roles..." etc., do not add substance to the IS phenomena, leaving it uncertain as to what elements do IS includes, which considerably complicates its measurement. We thus analyse the IS concept in detail, provide our vision of it and determine "e-readiness" tools as reflective numerical measures of the abstract IS concept. The definitions and the relations between the concepts of IS, e-readiness and digital divide, as discussed above, will serve as a basis for the following analysis of existing IS measurements and suggestions on their improvement.

\subsection{Existing information society measurements: a missing element}

A large number of various reports, case studies, questionnaires, surveys, models and position papers developed to measure ereadiness or its specific elements, can be used to measure it, or can be re-worked into such assessment tools (Bridges.org, 2005). In this 
section, we will analyse four of the most widely used indices for measuring IS. The indices were selected because:

- they are calculated annually or systematically (which is necessary for benchmarking purposes);

- their rankings cover a large number of countries, including developed, developing and less-developed states (which allows a full picture of the magnitude of the global digital divide to be obtained);

- their rankings or reports can be accessed via the internet, and their methodology and constituent indicators have been disclosed by the developers.

Prominent among the most widely used indices and those meeting the selected criteria are:

- ICT Development Index of International Telecommunication Union (ITU, 2010);

- Networked Readiness Index of World Economic Forum (World_ Economic_Forum_INSEAD, 2011);

- Digital Economy Rankings of Economist Intelligence Unit (Economist_Intelligence_Unit_IBM_Institute_for_Business_Value, 2010);

- Knowledge Economy Index of the World Bank (The_World_Bank, 2009).

Prior to analysing the conceptual frameworks of the selected indices, it may be useful to illustrate a typical index structure and describe its elements (Fig. 2). The complexity of an index structure usually depends on its goals, as set by the developers:

- if the developers want to create a composite measure of a onedimensional phenomenon, they usually construct a simple index, using only a set of indicators. The indicators composing a simple index are aggregated into a single index value using analytical methods/models selected by the developers;

- if the developers aim to create a composite measure of a multidimensional phenomena, like IS, it is useful to apply a complex index structure, with a breakdown into subindices, categories, subcategories, etc. The number of breakdowns can be limited to two (e.g. subindices and indicators), or include many (subindices, categories, subcategories, dimensions, pillars, indicators, etc.). The final index value is obtained by consecutive aggregation of the indicators into subcategories, categories, subindices and an index.

All of the four indices selected for this research have complex index structures with varying levels of complexity.

The ICT Development Index (IDI) was first presented in the 2009 edition of Measuring the Information Society by ITU. By uniting best practices and avoiding duplications of the Digital Opportunity Index and ICT Opportunity Index, which were endorsed during the Tunis phase of WSIS, this index seeks to measure the level of evolution of ICT development in countries and that relative to other countries over time, both in developed and developing states, as well as the potential of ICT for development, based on the capabilities and skills available. The conceptual framework of the index allows the measuring of the state of IS development by means of 11 indicators, following a threestage model: ICT readiness (access sub-index), ICT intensity (use subindex), and ICT impact (largely depends on the skills sub-index). The most recent 2010 edition of Measuring the Information Society (ITU, 2010) captured the IDI for 159 countries worldwide and measured their progress between 2002 and 2008.

The Networked Readiness Index (NRI), calculated annually by the World Economic Forum and INSEAD, is part of the Global Information Technology Report and aims to measure the propensity of countries around the world to use ICT as an enabler of economically and socially sustainable development and competitiveness. The Networked Readiness Index is comprised of 68 indicators, encompassing the majority of indicators, confirmed by the Partnership on Measuring ICT for Development. NRI's conceptual framework provides an assessment of the country's networked readiness in three logically connected dimensions: environment for ICT, with a breakdown into market, political-regulatory and infrastructure; readiness of three main national stakeholders (individuals, business, government) to use and benefit from ICT; and the level of stakeholders' ICT usage. Introduced for the first time in 2002, the most recent issue of the Global Information Technology Report (World_Economic_Forum_INSEAD, 2011) presented the 2010-2011 rankings of NRI, covering 138 worldwide economies.

The Economist Intelligence Unit's Digital Economy Rankings, previously known as "e-readiness rankings", capture the ability of countries around the world to absorb ICT and use it for an economic and social benefit. Thirty nine indicators, grouped into six pillars (connectivity and technology infrastructure, business environment, social and cultural environment, legal environment, government policy and vision, consumer and business adoption), assess the quality of a country's ICT infrastructure and the ability of its consumers, businesses and governments to use ICT to their benefit. Since the first introduction of the ranking in 2000, it has increased to covering 70 countries in 2010.

The Knowledge Economy Index is an integrated tool, developed by the World Bank, aimed at measuring the conduciveness of a country's environment to generate, use and diffuse knowledge effectively for economic development. The Knowledge Economy Index framework is based on the four pillars of knowledge economy (economic incentive regime to stimulate the efficient use of existing and new knowledge, innovation systems to create new knowledge and integrate them into the global stock of knowledge, education to create, share and use knowledge efficiently, ICT to facilitate processes of knowledge creation and distribution), which break down into 12 indicators. The most recent ranking of KEI (mainly 2005-2006) covered 145 economies worldwide.

These indices are summarised in Table 1, where we highlight the scope of the analysis (publication frequency and year of last issue, number of countries covered and subjects examined) along with the conceptual framework, methodology and main focus.

In order to ascertain the underlying nature of these indices, it is necessary to analyse the structure of their constituent indicators.

A substantial difference in terms of the number of indicators, constituting the selected indices, e.g. IDI-11, NRI-68, considerably complicates

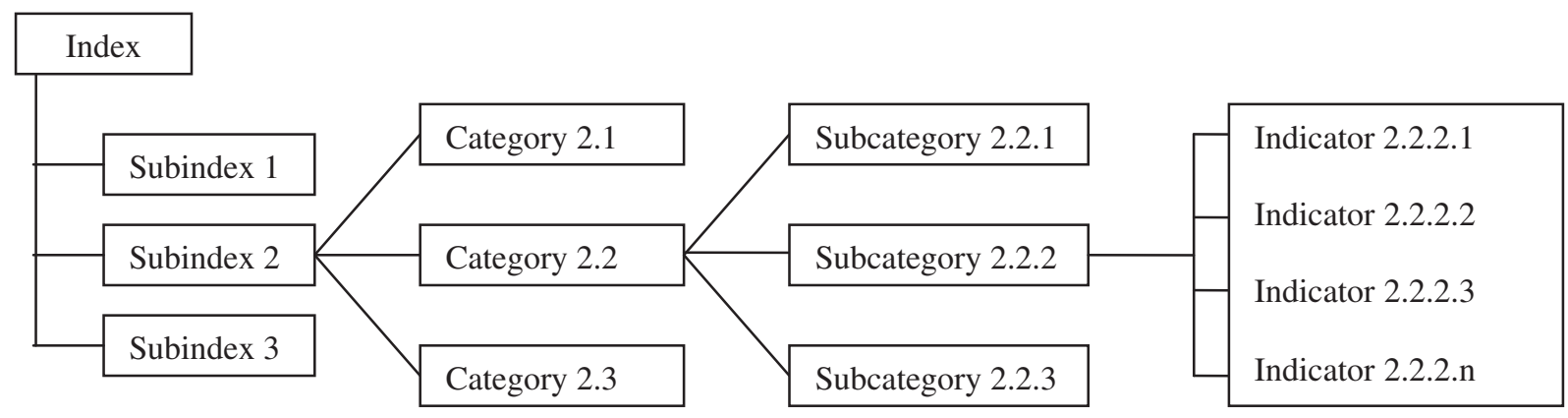

Fig. 2. Example of a typical index structure and its elements. 
Table 1

A. Summary of the selected information society indices.

\begin{tabular}{|c|c|c|c|}
\hline Index title/Developer & $\begin{array}{l}\text { Publication } \\
\text { frequency/ }\end{array}$ & $\begin{array}{l}\text { No. of countries covered in last issue } \\
\text { Main focus }\end{array}$ & Conceptual framework/methodology \\
\hline $\begin{array}{l}\text { ICT Development Index } \\
\text { (IDI)/ITU }\end{array}$ & Annual/159 & $\begin{array}{l}\text { Evolution of ICT developments and the development potential of } \\
\text { ICT, based on capabilities and skills available in the countries }\end{array}$ & $\begin{array}{l}\text { Three-stage IS model (readiness-use-impact) } \\
\text { Analytical model based on hard data from ITU }\end{array}$ \\
\hline $\begin{array}{l}\text { Networked Readiness Index (NRI)/World } \\
\text { Economic Forum and INSEAD }\end{array}$ & Annual/121 & $\begin{array}{l}\text { Propensity for countries to exploit the opportunities, offered by } \\
\text { ICT }\end{array}$ & $\begin{array}{l}\text { Three-stage networked readiness model (envi- } \\
\text { ronment-readiness-use) } \\
\text { Analytical model based on hard data from ITU, } \\
\text { WB, national sources, etc. and the Executive } \\
\text { Opinion Survey }\end{array}$ \\
\hline $\begin{array}{l}\text { Digital Economy Rankings/Economist } \\
\text { Intelligence Unit and IBM Institute for Busi- } \\
\text { ness Value }\end{array}$ & Annual/70 & $\begin{array}{l}\text { Capacity for countries to extract the maximum economic and } \\
\text { other benefits from the use of digital economy }\end{array}$ & $\begin{array}{l}\text { Six-element digital economy model } \\
\text { Analytical model based on data from the Econo- } \\
\text { mist Intelligence Unit }\end{array}$ \\
\hline Knowledge Economy Index/World Bank & $\begin{array}{l}\text { Non- } \\
\text { systematic } \\
\text { update/145 }\end{array}$ & $\begin{array}{l}\text { Conduciveness of countries' environment for knowledge to be } \\
\text { used effectively for economic development }\end{array}$ & $\begin{array}{l}\text { Four-stage know-ledge economy model (envi- } \\
\text { ronment-innovation-education-ICT) } \\
\text { Analytical model based on data from World Bank }\end{array}$ \\
\hline
\end{tabular}

B. Summary of the selected information society indices

\begin{tabular}{|c|c|c|}
\hline Index title/Developer & Subjects & Indicators, representing ICT usage \\
\hline $\begin{array}{l}\text { ICT Development Index } \\
\text { (IDI)/ITU }\end{array}$ & $\begin{array}{l}\text { 1) ICT infrastructure and access; } \\
\text { 2) ICT use; } \\
\text { 3) ICT skills } \\
\text { Which break down into } 11 \text { indicators }\end{array}$ & $\begin{array}{l}\text { 1) Internet users per } 100 \text { inhabitants; } \\
\text { 2) Fixed broadband internet subscribers } \\
\text { per } 100 \text { inhabitants; } \\
\text { 3) Mobile broadband subscriptions per } \\
100 \text { inhabitants }\end{array}$ \\
\hline $\begin{array}{l}\text { Networked Readiness Index (NRI)/World Economic } \\
\text { Forum and INSEAD }\end{array}$ & $\begin{array}{l}\text { 1) ICT Environment; } \\
\text { 2) ICT Readiness; } \\
\text { 3) ICT Usage } \\
\text { Each subindex is divided into } 3 \text { pillars. } \\
\text { Pillars of the Environment subindex: Market environment, political and } \\
\text { regulatory environment, Infrastructure environment. } \\
\text { Pillars of the Readiness subindex: Individual readiness, Business readiness, } \\
\text { Government readiness. } \\
\text { Pillars of the Usage subindex: Individual usage, Business usage, Government } \\
\text { usage } \\
\text { Which break down into } 68 \text { indicators }\end{array}$ & $\begin{array}{l}\text { Individual usage: } \\
\text { 1) Mobile telephone subscribers per } 100 \\
\text { population; } \\
\text { 2) Personal computers per } 100 \\
\text { population; } \\
\text { 3) Total broadband internet subscribers } \\
\text { per } 100 \text { population; } \\
\text { 4) Internet users per } 100 \text { population; } \\
\text { 5) International internet bandwidth per } \\
\text { 10000 population } \\
\text { Business usage: } \\
\text { 1) Prevalence of foreign technology } \\
\text { licencing; } \\
\text { 2) Firm-level technology absorption; } \\
\text { 3) Capacity for innovation; } \\
\text { 4) Availability of new telephone lines } \\
\text { 5) Extent of business internet use; } \\
\text { Government usage: } \\
\text { 1) Government success in ICT promo- } \\
\text { tion; } \\
\text { 2) Availability of government online } \\
\text { services; } \\
\text { 3) ICT use and government efficiency; } \\
\text { 4) Presence of ICT in government of- } \\
\text { fices; } \\
\text { E-participation Index }\end{array}$ \\
\hline $\begin{array}{l}\text { Digital Economy Rankings/Economist Intelligence Unit } \\
\text { and IBM Institute for Business Value }\end{array}$ & $\begin{array}{l}\text { 1) Connectivity and technology infrastructure; } \\
\text { 2) Business environment; } \\
\text { 3) Social and cultural environment; } \\
\text { 4) Legal environment; } \\
\text { 5) Government policy and vision; } \\
\text { 6) Consumer and business adoption } \\
\text { Which break down into } 39 \text { indicators }\end{array}$ & $\begin{array}{l}\text { 1) Broadband penetration as \% of the } \\
\text { total population; } \\
\text { 2) Mobile-phone penetration as \% of the } \\
\text { total population; } \\
\text { 3) Internet user penetration as \% of the } \\
\text { total population; } \\
\text { 4) Consumer spending on ICT per head; } \\
\text { 5) Level of e-business development; } \\
\text { 6) Use of internet by consumers; } \\
\text { Use of online public services by citizens } \\
\text { and business }\end{array}$ \\
\hline Knowledge Economy Index/World Bank & $\begin{array}{l}\text { 1) Economic incentive regime; } \\
\text { innovation; } \\
\text { education; } \\
\text { ICT } \\
\text { Which break down into } 12 \text { indicators }\end{array}$ & $\begin{array}{l}\text { 1) Telephone penetration per } 1000 \\
\text { people; } \\
\text { 2) Computer penetration per } 1000 \\
\text { people; } \\
\text { 3) Internet penetration per } 1000 \text { people }\end{array}$ \\
\hline
\end{tabular}

the analysis and adequate comparison of separate indicators, which makes it more reasonable to look at them in a broader sense-their interrelation within an index.

By taking a closer look at the subjects disclosed in the selected indices and their constituent indicators, it can be observed that many of them, despite varying formulation and position in the index structure, address similar aspects of IS development with different levels of detail. As suggested by Bridges.org - an international NGO aiming to help people in developing countries use ICT to improve their lives - these aspects reflect five major considerations of e-readiness: 
1. technology (infrastructure-network and, teledensity, pricing, speed and quality, other technology issues)

2. economy (use within businesses, e-commerce, market competition/ privatization, export trade and foreign investment, other economic or business factors)

3. government (policy, privacy, trade, intellectual property, electronic signatures; regulations, e-government, political openness and democracy)

4. education (use of ICT in schools, tech training in schools, availability of trained workforce)

5. social (use of ICT in everyday life, utilization of technology throughout society-inequality, basic literacy, poverty, other social factors, locally relevant content, consumer trust, unique political, business, social history).

The abovementioned groups and their constituents comprehend the most important generalised dimensions of e-readiness and can be further used to analyse IS indices.

By elaborating on the e-readiness tools comparison tables developed by (Bridges.org, 2005), we have calculated a percentage distribution of indicators between five groups (technology, economy, government, education, social) within each index, as it can be seen in Table 2 below.

As the comparisons above show, IS measurement tools are very diverse in terms of their conceptual frameworks and goals, as well as their constituent indicators, interrelations between them and, thus, the major focus of the tool. While the ICT Development Index is clearly infrastructure-focused, with no indicators covering economy, legal or educational aspects of IS building, the Digital Economy Rankings are more economy-orientated, whereas the Networked Readiness Index and Knowledge Economy Index are comprehensive tools, with the distribution of their indicators being more or less balanced.

The structure of the tools, however, fully reflects their conceptual frameworks and the differences in their goals, as posed by their developers. Since the ICT Development Index seeks to measure the evolution of ICT development and the potential of ICT for development, based on the available capabilities and skills, infrastructural and social indicators are pervasive in this tool. Similarly, Digital Economy Rankings fully relate to their title, and are mainly focused on reflecting the influence of ICT on the economic process. In contrast, the Networked Readiness Index and Knowledge Economy Index pose general goals to measure the country's readiness to exploit the opportunities offered by ICT.

In this respect we must conclude that each of the tools analysed works well for its intended purpose. Thus, "the right tool depends on the user's goal. The user should choose a tool that measures what they are looking for, and does it against a standard that fits their own view of an e-ready society" (Bridges.org, 2005).

As can be understood from the discussion on the topics of IS, ereadiness and digital divide, our vision of the comprehensive nature of the IS concept foresees using comprehensive tools to measure it. While single topic-focused tools can be used to measure certain aspects of IS development, if we are to measure IS as a fully-fledged phenomena, we must address all of its elements in a coherent manner.

The Networked Readiness Index fully corresponds to our definition of a comprehensive IS measurement tool, including both indicators

Table 2

Distribution of indicators between five major groups after (Bridges.org, 2005).

\begin{tabular}{llllll}
\hline & Technology & Economy & Government & Education & Social \\
\hline $\begin{array}{l}\text { ICT Development Index } \\
\text { Networked Readiness }\end{array}$ & $71 \%$ & - & - & - & $29 \%$ \\
$\quad$ Index & $21 \%$ & $25 \%$ & $9 \%$ & $19 \%$ & $26 \%$ \\
$\begin{array}{l}\text { Digital Economy } \\
\quad \text { Rankings }\end{array}$ & $23 \%$ & $41 \%$ & $20 \%$ & $13 \%$ & $3 \%$ \\
$\begin{array}{l}\text { Knowledge Economy } \\
\text { Index }\end{array}$ & $23 \%$ & $19 \%$ & $16 \%$ & $16 \%$ & $26 \%$ \\
\end{tabular}

on ICT adoption (ICT Usage sub index) and indicators that mark the propensity for countries to exploit opportunities, offered by ICT (Environment sub index and Readiness sub index). While also being a comprehensive tool, the Knowledge Economy Index is inferior to the Networked Readiness Index in terms of a lower variety of indicators (68 in NRI to 12 in KEI) and worse regularity of measuring these, which is necessary for benchmarking and tracking progress purposes (annual for NRI and non-recurring for KEI).

The NRI is ahead of other currently used measurement indices because it is supported by a sound conceptual framework. The framework consists of a wide range of well-distributed and systematic measured indicators encompassing the majority of those in the Core list of ICT indicators.

However, despite all the positives with respect to the currently used indices, they are all subject to a certain limitation: they fail to highlight the deep meaning of ICT usage and to distinguish between its manifests. As comparisons in Table 1 show, indicators representing ICT usage in the selected indices are mainly "quantitative"-that is, indicators, measuring the number of individuals, businesses, governments, and household users of ICT in general (e.g. proportion of households with a personal computer, mobile cellular subscriptions per 100 inhabitants).

A deeper look at the concept of ICT usage allows for tracing its various manifestations. For instance, the general number of ICT users can be disaggregated by a range of qualitative characteristics, like place and means of access, frequency, proficiency, and purpose of ICT usage. Each of the abovementioned qualitative characteristics can also be broken down or combined and presented in a form of indicators for further measuring and comparing. In this article, we use the terms "indicators of the quality of ICT usage" (or shortly-"qualitative") regarding these indicators that disclose qualitative characteristics of the general ICT usage in a country.

While "quantitative" indicators of ICT usage are traditionally used for international digital divide assessment, namely indicators of the quality of ICT usage should serve as a basis for "second order" digital divide evaluation, will more accurately and profoundly reflect national and international inequalities in the efficiency use of ICT for the purpose of development. Indicators of the quality of ICT usage are, thus, the missing elements in the currently used IS measurement indices.

The Core list of ICT indicators (Partnership_on_MeasuringICT_for_Development, 2010) outlines particular "qualitative" indicators of ICT usage that national statistical agencies should assess and thus wisely contribute to achieving internationally comparable and reliable ICT statistics. For example, indicators on the use of ICT by households, individuals and businesses are specified by the following qualitative criteria (indicators):location of ICT use, frequency of ICT use, type of access and types of activities undertaken using the internet. Each criterion (indicator) is further disaggregated into defined response categories. For instance, indicator on the location of individual use of the internet in the last 12 months is disaggregated into the following options (indicators): work, home, place of education, another person's home, community internet access facility, commercial internet access facility, any place via a mobile cellular telephone, and any place via other mobile access device. Each of the defined response categories could be also considered to be a separate indicator.

Likewise, the types of internet activities undertaken by individuals can be broken down into 14 indicators: getting information about goods or services; getting information related to health or health services; getting information from general government organisations; interacting with general government organisations; sending or receiving e-mails; telephoning over the internet/VoIP; posting information or instant messaging; purchasing or ordering of goods and services; internet banking; education or learning activities; playing or downloading video games or computer games; downloading movies, images, music, watching TV or video, or listening to radio or music; downloading software; and reading or downloading online newspapers or magazines and electronic books. 
The Core list contains over 40 indicators, disclosing numerous qualitative characteristics of ICT usage, which can be easily accessed online.

However, statistics on the indicators, outlined in the Core list, is not being collected in most of the countries due to the high cost and difficulties of obtaining such multi-faceted information. The omission of "qualitative" indicators of ICT usage in the current IS measurement practice is mainly related to the problem of data gathering.

The lack of information on the actual levels of ICT usage in the widely used IS measurement tools results in an incomplete vision of the state of IS building within and between countries. Shortage of data as to why and how ICT is used, what are the obstacles to ICT usage, and how can ICT usage be enhanced, does not allow the identification of specific areas of concern that require special attention from policy-makers in order to build a responsive IS, addressing the needs of its stakeholders.

Moreover, limited statistics on ICT use creates obstacles for measuring ICT impacts-the next step in the chain of IS measurement. It is definitely difficult, if not impossible, to gauge whether or not ICT is a driver of social-economic development without adequate data on the quality of ICT usage.

Whereas some authors have highlighted the importance of measuring actual levels of ICT usage (Dewan \& Frederick, 2005; Ferro, Helbig, \& Gil-Garcia, 2011; Menou \& Taylor, 2006), and attempts to conduct such research have been made at the levels of individuals and households within different states (Devins, Darlow, \& Webber, 2008; DuquaineWatson, 2006; Gang, 2010; Goldfarb \& Prince, 2008; Jackson et al., $2005,2007)$, we could not identify studies that would use states as measurement units for such calculations. In our opinion, studies like that would provide a fresh look on the dynamics of global digital divide.

The aim of the next section is to show how the incorporation of indicators on the actual levels of ICT usage in the process of IS measurement will provide a better understanding of the state of IS development within countries, and thus be a helpful tool for IS policy-makers, and whether calculation of the differences between states in terms of actual levels of ICT usage will provide a more profound picture of global digital divide dynamics.

\section{Toward an integrated measure of information society and digital divide}

In this section, we develop a framework for incorporating the actual levels of ICT usage into the process of IS measurement. We argue that it is important to take into consideration actual levels of ICT usage, because they allow researchers and policy-makers to obtain a profound understanding of the level of IS development in a specific country. Furthermore, if considered together with e-readiness measures, the levels of ICT usage help to define links between state policies of IS building and actual levels of ICT implementation, and suggest areas and actions for improvement.

\subsection{Data and methods}

The analysis of the currently used indices for measuring IS and digital divide, conducted above, has detected their limitation in terms of constituent indicators. While "quantitative" indicators of ICT usage are well exposed in most of the widely used indices, "qualitative" indicators remain highly underrepresented. Indicators on the quality of ICT usage carry the potential of uncovering implicit incentives and barriers to effective ICT usage, which makes them helpful tools for researchers and policy-makers in the area of IS. To test this, we will construct an ICT Usage Index to calculate the magnitude of the "qualitative" digital divide, and then compare it with the magnitude of the "quantitative" digital divide (using NRI rankings as a basis) to see whether they follow the same pattern and whether the newly detected interrelations offer the possibility to obtain a deeper understanding of the peculiarities of the IS development process.
An index is constructed by taking into account the unique set of indicators from which it is formed. "Qualitative" indicators of ICT usage generally reflect the level of efficiency of ICT implementation in a country. Information on whether or not a country's stakeholders use ICT for: gaming or information searching once a month or daily, use a PC or a borrowed utility, etc., provides an insightful view on the peculiarities of the ICT implementation process in a country.

At the same time, these "qualitative" ICT indicators are consecutive characteristics in the chain of IS development measurement. This is because they reflect the effectiveness of the ICT-enabling policies of the state, namely:

- the conduciveness of the political-regulatory, market and infrastructure environment for ICT adoption in the country (as measured by NRI's Environment subindex);

- the level of individual, business and government readiness to efficient ICT usage (as measured by NRI's Readiness subindex);

- actual levels of ICT usage with the purpose of economic growth and development.

The ability of a country's stakeholders to use ICT effectively depends largely on a broad number of factors: from general economic factors (like laws relating to ICT and burden of government regulation) to individual or business specific factors (quality of education, computer, communications and other services imports). By incorporating all these factors, ICT-enabling policies are set to facilitate ICT usage in all spheres of public life in a country.

Thus wise, ICT-enabling policies and efficiency of ICT usage are closely related: with ICT-enabling policies being a prerequisite for efficient ICT usage, and with ICT usage (high or low) being a reflector of the effectiveness (high or low) of such policies.

With this in mind, we will consider "qualitative" indicators of ICT usage in the EU countries in conjunction with the elements of the Networked Readiness Index, namely its subindices. This will allow for tracing of the links between positive or negative dynamics of ICT usage indicators and ICT-enabling policies in the countries, and, according to the findings, to detach and emphasise the main areas of focus that require immediate governmental attention and improvement.

European Union member states are selected for testing as the only countries that regularly monitor the development of IS with a broad number of indicators on the quality of ICT usage, particularly under the EU "i2010 Benchmarking Framework" (European_Commission, 2010) and its current successor the "Benchmarking Digital Europe 2011-2015" framework (European_Commission, 2009a). Since data on the newly endorsed benchmarking framework is not yet available, data from the 2009 Europe's Digital Competitiveness Report (European_Commission, 2009b) will be used as a basis for calculations.

The "i2010 benchmarking framework" was endorsed by the i2010 High Level Group in April 2006 to track the progress of the i2010 strategy: "i2010-A European Information Society for growth and employment"(European_Commission, 2010). Annual comparative analysis is realised on the basis of a set of indicators, covering various aspects of IS development: broadband; internet usage; take-up of internet services; e-government; e-commerce; e-business; ICT sector, ICT skills and R\&D. Fourty four indicators of the "i2010 benchmarking framework", that reflect namely qualitative aspects of ICT usage, are chosen for further ICT Usage Index development and testing (see Appendix A for the list of indicators).

Bringing a variety of indicators into a single composite measure will allow making an immediate evaluation of the evenness and dynamism of IS development between the EU member states. Moreover, the construction of a composite measure of IS development will correspond to the recommendation, adopted during the WSIS in Geneva (WSIS, 2003b), which calls on the international community for the creation of a composite ICT index in order to track the progress in the IS development initiative. 
At the same time it is important to notice, that development of composite measures can also carry potential drawbacks. If not fully explained and validated, the selection of components, their weightings and structure of composite indices leaves room for manipulation that can lead to obtaining biased view on the subject measured. Full information and profound justification of a composite index development process are crucial in this respect.

\subsection{Testing}

The following steps will be further taken:

1) calculation of a single EU ICT Usage Index using data from the EU member states and NRI methodology in order to provide comparability of the results;

2) estimation of the received ICT Usage Index values, finding intraEuropean patterns of ICT usage and the scale of the digital divide;

3) comparison of the ICT Usage Index values with the corresponding values of countries' Networked Readiness Index, finding patterns and interrelations.

\subsubsection{Calculation of a single EU ICT Usage Index}

The procedure of a single EU ICT Usage Index calculation consists of a set of subsequent stages. The first stage of ICT Usage Index construction lies in the process of identifying indicators that will form its structure. In order to ensure the objectiveness and validity of the selection process, a statistical method of multivariate analysis, namely principal components analysis (PCA), was used to extract statistically informative indicators from the initial set of 44 indicators, and to discard those indicators that are statistically similar or insignificant. In such a manner, conducted in the STATISTICA Program PCA, it allowed the process of index calculation to be simplified owing to the reduction of the initial number of indicators to 35 (see Appendix A for detailed description of the PCA process). Herein the selected indicators carry the same statistical meaning as the whole set of indicators together.

The next stage is the successive normalisation of the statistical data to the scale of 1-7 ( 7 is the best possible value) using the standard NRI normalisation formula.

The final stage is the successive aggregation of the normalised values at the level of subindices with further aggregation into a single value of the ICT Usage Index (see Appendix A for details on the construction of the ICT Usage Index).

The final values of the 2009 ICT Usage Index and its subindices for the EU member states are presented in Table 3.

\subsubsection{Estimation of the ICT Usage Index values obtained}

The index values enable us to determine the following: there are considerable differences in the index values of the researched countries, which is an indication of IS fragmentation in the EU and the presence of a distinct digital divide between its member states. By using range as a grouping measure, the following groups of countries emerged: $1 \mathrm{st}$ group-countries with low levels of ICT usage, index values ranging from 1.0311 to 2.3274 (Romania, Cyprus, Bulgaria, etc.); 2nd groupcountries with medium levels of ICT usage, index values ranging from 2.3274 to 3.6236 (Belgium, Austria, Ireland, etc.); and 3rd groupcountries with high levels of ICT usage, index values ranging from 3.6236 to 4.9199 (Norway, Denmark, Netherlands, etc.). Further research should focus on changes in the group structures and on the dynamics of index value development. This can lead to conclusions about the digital divide reduction or growth. At the present time, however, full rankings are only available for 2009.

\subsubsection{Comparison of the ICT Usage Index values}

Having calculated the ICT Usage Index values and subindex values, it is useful to compare the results received with the values of the Networked Readiness Index and its subindices. Presumably, it will let us identify the causes of negative dynamics in certain areas and consider

Table 3

ICT Usage Index and its subindex values for the EU member states, 2009.

\begin{tabular}{|c|c|c|c|c|c|c|c|}
\hline Subindex/Index & Internet usage & Take up of internet services & e-business & e-commerce & e-government & Broad band & ICT Usage Index \\
\hline \multicolumn{8}{|l|}{ Country } \\
\hline Austria & 2.7308 & 3.2478 & 5.2979 & 4.2252 & 4.9232 & 4.7646 & 3.4629 \\
\hline Belgium & 2.7903 & 2.9938 & 5.6917 & 4.1014 & 3.4953 & 5.4279 & 3.5656 \\
\hline Bulgaria & -0.2702 & 1.4346 & 4.7632 & 1.0000 & 1.8419 & 2.4699 & 1.5994 \\
\hline Cyprus & -0.0668 & 1.6590 & 2.1493 & 1.7647 & 2.6118 & 2.7317 & 1.4195 \\
\hline Czech Republic & 1.3898 & 2.3335 & 2.5128 & 4.1002 & 3.3965 & 4.2161 & 2.4904 \\
\hline Denmark & 4.3769 & 5.6143 & 6.3232 & 5.5726 & 5.7208 & 6.1667 & 4.7641 \\
\hline Estonia & 2.4708 & 3.6783 & 3.7687 & 2.2835 & 5.0717 & 4.6016 & 2.8826 \\
\hline Finland & 4.1179 & 5.4239 & 4.7199 & 3.7894 & 5.4982 & 5.3303 & 3.9791 \\
\hline France & 2.5666 & 4.1935 & 3.9252 & 3.3692 & 5.3107 & 5.1976 & 3.2942 \\
\hline Germany & 3.0691 & 4.3427 & 4.3008 & 5.3406 & 3.7205 & 5.1646 & 3.7711 \\
\hline Greece & -0.2345 & 1.5882 & 3.4971 & 1.6924 & 3.4402 & 2.7423 & 1.6096 \\
\hline Hungary & 1.8209 & 3.2261 & 2.2904 & 2.3378 & 3.3085 & 3.6013 & 2.2701 \\
\hline Ireland & 1.9048 & 2.6262 & 4.7175 & 6.1524 & 4.7751 & 4.3869 & 3.3790 \\
\hline Italy & 0.4898 & 1.7762 & 3.3923 & 1.5149 & 3.6303 & 4.1143 & 1.9479 \\
\hline Latvia & 1.9286 & 3.5371 & 2.8719 & 2.0734 & 2.4628 & 3.7292 & 2.4015 \\
\hline Lithuania & 1.2544 & 2.7304 & 3.1392 & 3.8627 & 4.2741 & 3.1532 & 2.4297 \\
\hline Luxembourg & 3.9468 & 5.0623 & 4.6453 & 3.3653 & 4.5035 & 5.8638 & 3.8836 \\
\hline Malta & 0.8475 & 2.7508 & 5.1926 & 4.1255 & 3.8643 & 4.2460 & 2.9319 \\
\hline Netherlands & 4.3824 & 5.7698 & 6.1511 & 5.3557 & 6.0807 & 6.0209 & 4.7038 \\
\hline Poland & 0.8346 & 2.3017 & 2.5179 & 2.4756 & 3.0652 & 2.2357 & 1.7810 \\
\hline Portugal & 0.1887 & 2.0857 & 5.9087 & 3.8476 & 4.4730 & 4.4424 & 2.8252 \\
\hline Romania & -1.0000 & 1.2939 & 2.5861 & 1.2011 & 2.0088 & 1.8419 & 1.0311 \\
\hline Slovakia & 2.4748 & 3.0069 & 4.5465 & 2.1002 & 4.2323 & 3.2501 & 2.6328 \\
\hline Slovenia & 1.4895 & 3.3051 & 3.4567 & 3.0011 & 4.6603 & 4.1753 & 2.6526 \\
\hline Spain & 1.2737 & 2.9416 & 2.6481 & 2.8275 & 3.7677 & 4.6912 & 2.4634 \\
\hline Sweden & 4.5173 & 5.5245 & 4.2343 & 5.1193 & 5.3431 & 5.8661 & 4.2932 \\
\hline United Kingdom & 3.2329 & 4.8247 & 1.6726 & 6.6303 & 4.0617 & 5.5191 & 3.7174 \\
\hline Iceland & 5.0000 & 5.8465 & 3.3208 & 4.5692 & 5.9737 & 6.0378 & 4.2217 \\
\hline Norway & 4.7450 & 5.8721 & 5.7496 & 6.4745 & 5.6468 & 6.1485 & 4.9199 \\
\hline Croatia & 0.1575 & 2.0614 & 4.8148 & 2.9641 & 1.8034 & 4.0792 & 2.3810 \\
\hline
\end{tabular}


them in the further process of development of concrete measures to lessen the scope of digital divide among the EU member states in the course of national IS strategy improvement.

For illustration purposes, the values of ICT Usage Index and Networked Readiness Index (and its Usage subindex) are assembled together in a graph.

By comparing the levels of IS development between EU member states using the ICT Usage Index and Networked Readiness Index (Fig. 3), it may be inferred that the ICT Usage Index averages and its max and min values are considerably lower than the analogous values of the Networked Readiness Index and its Usage subindex. Thus, if by the traditional indicators of ICT usage by individuals, businesses and governments, that are used to calculate the NRI Usage subindex, the EU member states reach optimal levels of usage, then by the "qualitative" indicators, which bring a deeper meaning to the term "ICT usage", the researched countries slowly expand the pace of ICT adoption.

It is also important to mention that the efficiency of ICT usage in the EU is marked by a significant variance in range (3.88), which is an indication of a distinct intra-European digital divide. While the graphical representation of the Networked Readiness Index is more even (variance range of 2.05).

Furthermore, even though the ICT Usage Index trend line reflects the NRI trend line, a number of countries, namely Estonia, Cyprus and Romania, considerably diverge from the general trend line of the ICT Usage Index, resulting in special interests in them.

Estonia generates particular interest, since it actively elaborates and implements innovative IS development programs, but holds a moderate 15th position in the ICT Usage Index ranking among the EU member states. In order to discover the causes of such a situation, it is necessary to examine the Estonian position in the ICT Usage Index subindex rankings. As may be inferred from Table 2, Estonia holds leading positions in e-government and take-up of internet services, its scores on internet usage and broadband are also higher than the EU averages. But at the same time, Estonia considerably lags behind leader-states in terms of e-commerce (23rd position) and e-business (17th position) development.

When comparing the results received with the Estonian scores on NRI and its Environment pillars, it can be argued that moderate levels of infrastructure development influenced considerably low levels of ICT usage within a country (see Fig. 4).
Since the level of infrastructure development is in many aspects decisive regarding the Readiness and Usage subindices, Estonian IS policy-makers should pay high attention to solving problematic issues in this pillar. Detailed analysis of indicators, which form the NRI Infrastructure environment pillar, shows that Estonia lags behind highly developed countries in terms of educational expenditures (40th position in the ranking), which, in turn, results in the low availability of scientists and engineers (70th position). Since the level of educational expenditure and availability of highly-qualified professionals in engineering, mathematics and sciences directly influence the innovation potential of various branches of the economy, including the ICT sector, and also all the indicators of the Readiness and Usage subindices, maximum effort should be focused on improving these indicators.

Furthermore, the graphical representation of ICT Usage Index and NRI Readiness pillars (see Fig. 5) clearly shows that such a low level of ICT integration in the daily activity of Estonian enterprises (only $11 \%$ and $18 \%$ of Estonian enterprises buy and sell online; apart from the indicators on electronic document exchange and e-invoices-Estonia thus holds the last position in the e-business subindex) is caused by the low level of business readiness to implement and effectively use ICT with the purpose of productivity growth. Business readiness is the only NRI pillar, which ranks Estonia at a rather low 32nd place in the ranking, when taking into account the very high Estonian scores in the pillars of government and individual readiness (7th and 19th position), as well as good levels of market, political-regulatory and moderate levels of infrastructure environment development.

Thus, in order to reverse the trend and increase the level of ICT integration in the internal business-processes of Estonian enterprises, to activate their ICT usage, particularly with regard to e-commerce which in turn will result in considerable economic benefit, it is necessary to focus the national IS strategy on the improvement of those factors that define the level of business readiness to efficient ICT usage. A detailed analysis of indicators, which forms the NRI business readiness pillar and their values for Estonia, allows for determining specific problematic indicators and tasks that require particular attention in the course of national IS building, such as: staff training, expansion of specialised research and training services, state promotion of $R \& D$ activities in the enterprises, state promotion of management schools upgrading, lowering the cost of business telephone connections and monthly subscriptions, harmonising university-industry research collaboration.

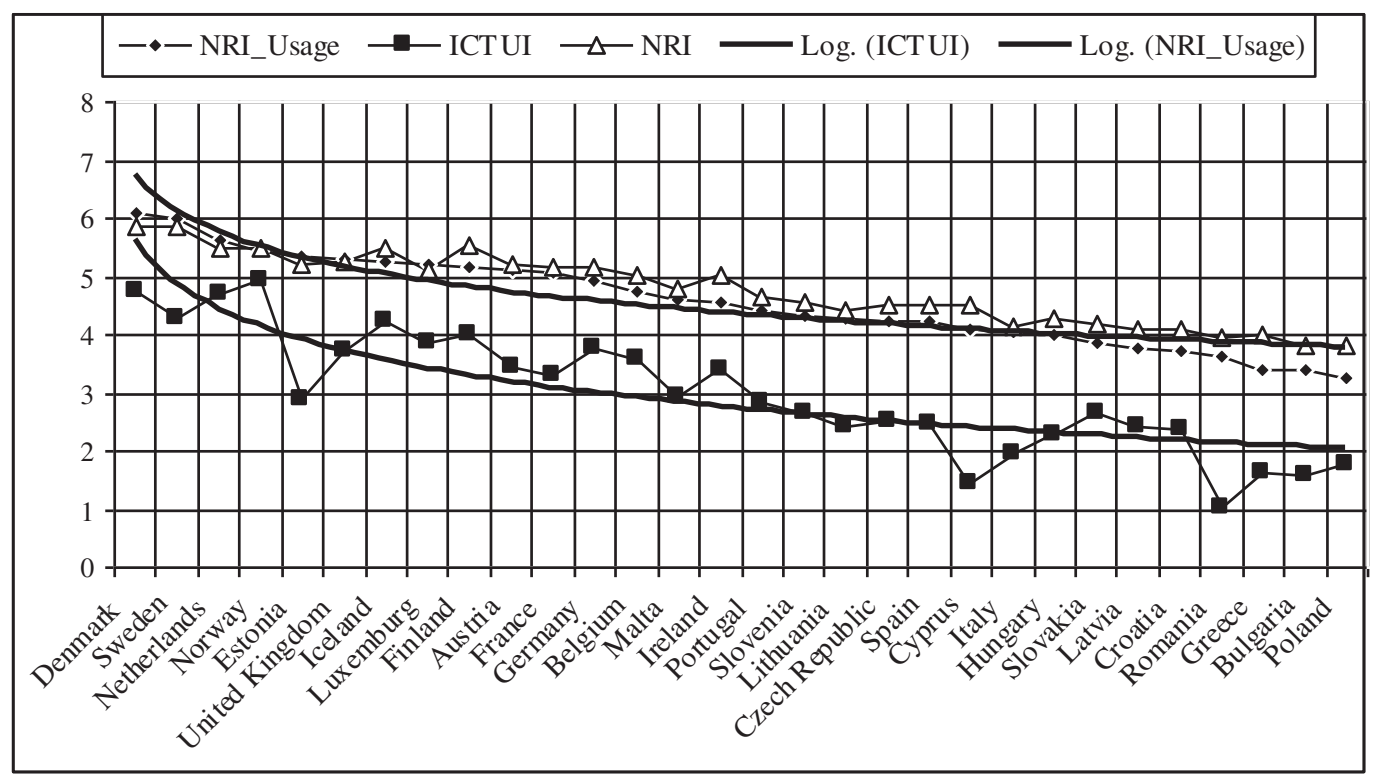

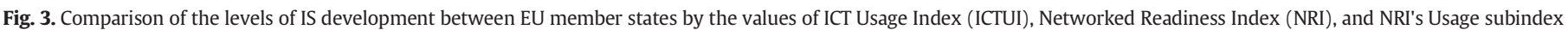
(NRI_Usage). 


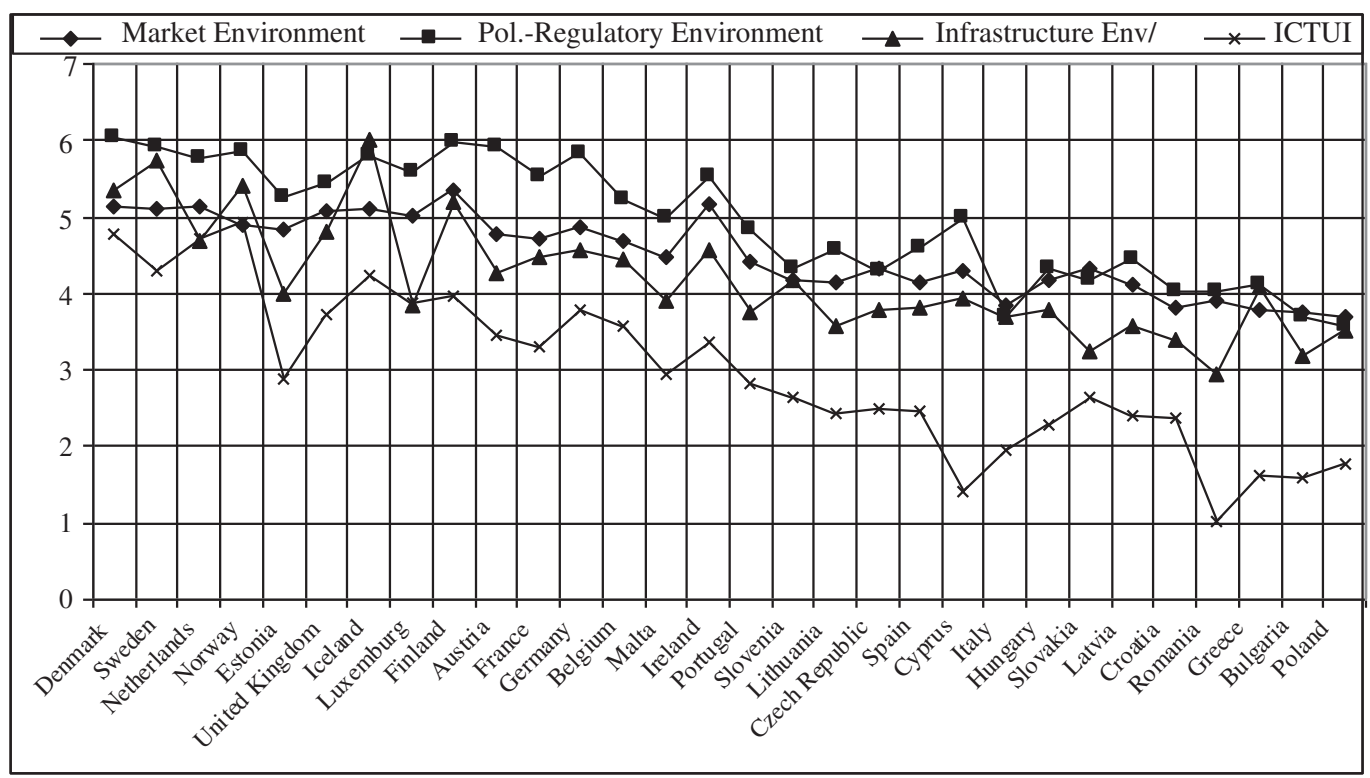

Fig. 4. ICT Usage Index (ICTUI) and NRI's Environment pillars (market, political and regulatory, infrastructure) combined.

Taking into account the particularly favourable political-regulatory and market environment in Estonia, and also the high levels of individual and government readiness, it is expected that Estonia will rapidly reach high levels of ICT usage by businesses and close the digital gap with the leading EU states, provided that the abovementioned conditions are accomplished.

The case of Cyprus is also interesting for detailed investigation, considering that Cyprus holds a rather high position (33d position among 121 countries) in the NRI ranking, while being among the laggards in the ICT Usage Index rating.

As may be inferred from Table 2, Cyprus performs low rates of all ICT Usage subindices, whereas internet usage (27th position), the take-up of internet services (27th position) and e-commerce (26th position) are particularly low among the EU member states. The fact that more than half of the Cyprian population has never used the internet, e-commerce accounts for only $1 \%$ of total turnover of enterprises, and only $7 \%$ of enterprises selling online, is quite challenging.
Comparison of the results received with the Cyprian scores on NRI and its Environment and Readiness pillars (see Figs. 4 and 5) suggests that causes of the problems lie in the pillars of Infrastructure environment and Business readiness.

While Cyprian score on Infrastructure environment pillar is generally rather high (27th position among 121 countries), detailed analysis of its constituent indicators shows that Cyprus lags behind highly-developed countries in terms of quality of scientific research organisations (63d position) and tertiary enrolment (62nd position). Moreover, low quality of scientific research organisations and low tertiary enrolment are further transformed in the low levels of Business readiness, namely the extent of staff training (56th position), local availability of research and training services (49th position), university research collaboration (59th position), and local supplier quantity (60th position).

Thus, low availability, quality and popularity of national scientific and research organisations contribute to the low rates of internet-user sophistication of the Cyprian citizens, which is further reinforced in the low integration of ICT in the economy.

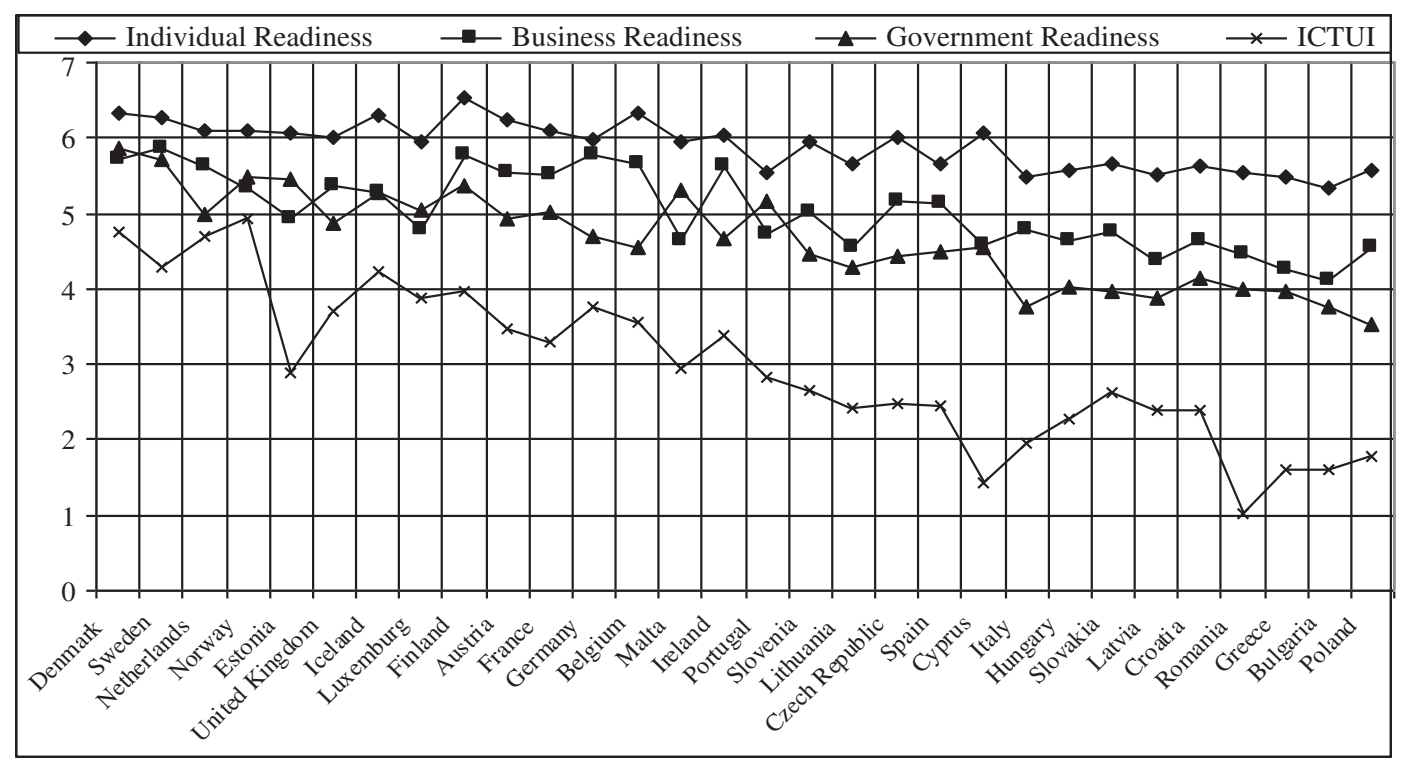

Fig. 5. ICT Usage Index (ICTUI) and NRI's Readiness pillars (individual, business, government) combined. 
In order to reverse the trend and increase the take-up of internet services by business and population in Cyprus, it is important to focus maximum effort on solving the outlined problematic issues in the pillars of Infrastructure environment and Business readiness.

Romania also generates significant interest, since it occupies the last positions in the EU ratings of the ICT Usage Index and its subindices. Generally, this situation indicates that Romanian IS is still at the development stage and requires a sophisticated development strategy. This is supported by the fact that Romania holds a moderate position in the Networked Readiness Index ratings (55th position among 121 countries), whereat the most difficult situation is intrinsic to the pillars of market and infrastructure environment (67th and 61st positions), and business and government readiness (68th and 64th positions).

Even though the Romanian government carried out a number of initiatives as part of the i2010 strategy (namely bringing into action an electronic system of state provisioning, opening an e-Romania portal, and starting the e-store project), the lack of a single national IS development strategy aimed at combating the digital divide and promoting economic growth, has resulted in the low effectiveness of the launched initiatives.

In turn, in order to reverse the trend and increase the levels of Romanian ICT usage, a complex and sophisticated IS development strategy is needed, which would address all the problematic aspects.

In summary of the analysis performed above, it may be useful to provide a sequence of steps that have been taken along its process.

a. A single ICT Usage Index of EU member states has been calculated and estimated with a view to digital divide occurrence and its scale.

b. The ICT Usage Index values have been compared with the corresponding values of countries' Networked Readiness Index and its Usage subindex to find patterns of ICT usage and interrelations. Three of the most distinguishing countries in terms of ICT Usage Index values have been selected for further research.

c. By means of graphical comparisons of the countries' values of ICT Usage Index, NRI's Environment pillars (Fig. 4) and Readiness pillar (Fig. 5), an analysis has been conducted to detect weak links in the systems of national e-readiness, which are reflected in the lower levels of ICT usage.

d. An in-depth analysis of the discovered problematic pillars and their constituent indicators has been further carried out to detect specific shortcomings and to suggest corresponding actions aimed at improving national IS policies.

The abovementioned approach to measuring IS can be likewise applied for other countries, The analysis of the graphical comparisons of the ICT Usage Index and Networked Readiness Index values of the other states allows the prompt detection of the most problematic areas and the suggestion of adequate measures to solve them. For instance, IS policy-makers in the Netherlands and in the United Kingdom should focus their attention on improving the infrastructure environment and government readiness; in Luxembourg-on upgrading infrastructure environment and business and government readiness; in Malta-on improving infrastructure and business environment, as well as business readiness; in Italy and Spain-on up-scaling government readiness and the systematic development of all elements of the Environment pillars, etc. A more detailed analysis of indicators, forming the problematic areas detected, will allow for suggesting specific measures to improve national policies of IS building.

Taking all this into consideration, the following integrated IS evaluation framework was developed (see Fig. 6). The framework combines both "qualitative" (as measured be the ICT Usage Index) and "quantitative" (as measured by the Networked Readiness Index) elements of IS development and can be used by IS researchers and policy-makers to:

- assess the level of a country's readiness to participate in the information economy and to effectively use the opportunities that arise from innovative information and communication technologies (by using the Networked Readiness Index values);

- assess the level of efficiency of ICT implementation in all spheres of public life in a country (by using the ICT Usage Index values);

- find reasons for negative or positive dynamics and suggest areas and actions for improvement (by comparing the values of the NRI and ICT Usage Index values, finding patterns and interrelations).

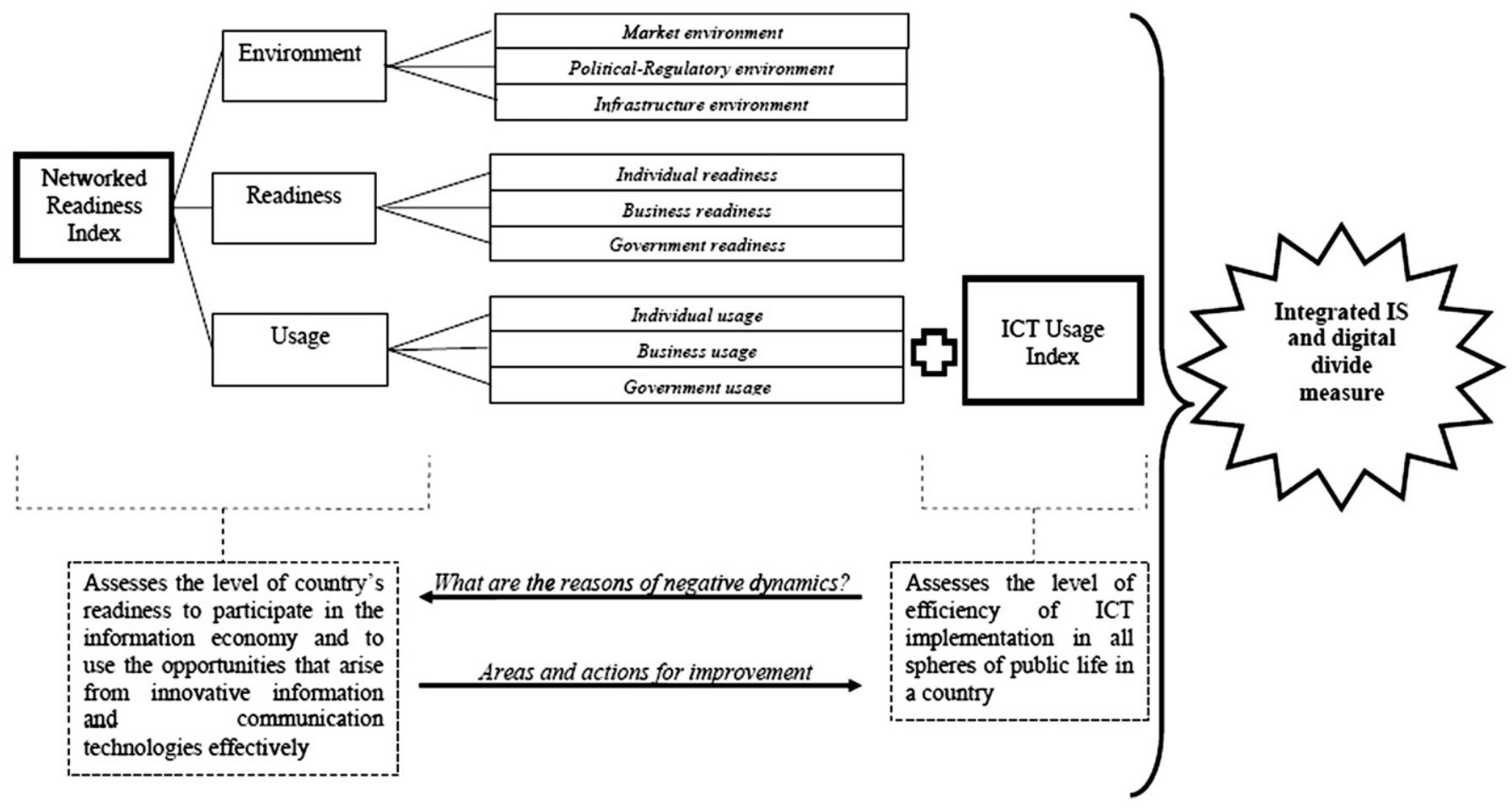

Fig. 6. Integrated information society and digital divide evaluation framework. 
According to the framework above, the ICT Usage Index in conjunction with the Networked Readiness Index form a composite measure of IS and international digital divide dynamics. By comparing the values of the constructed index the evenness or asymmetry of IS development between EU member states can be determined. The exposed digital divide, in this case, characterises the difference in the levels of development of the whole range of IS constituents, which corresponds to the complex essence of this phenomenon.

\section{Discussion and future research directions}

Fostered by a series of global initiatives, the last decade has witnessed a prolific development of a range of measurement tools. Their aim is to assess the state of countries' IS development and the scope of the digital divide between them. While such tools share important awareness-raising, informative and best practice goals, their great variety and different focuses create the risk for policy-makers to be trapped within a narrow vision of IS, which can lead to inadequate decision-making and other IS policy shortcomings.

In this article we review four of the most widely used indices for IS measurement from the position of their constituent indicators, to detect their main focus, feasibility and usefulness for further decision-making. Depending on their conceptual frameworks and goals, each of the analysed indices focuses either on a specific aspect of IS (economy, technology, etc.) or aims to provide a more or less balanced picture of all IS areas. Within the limits of their goals and constituent indicators, the selected indices work well for their intended purposes and can be useful for the respective decision-making.

By stressing the usefulness of the existing composite measures of IS development, we at the same time emphasising their limitation, in that they lack important indicators on the quality of ICT usage within countries. We suggest an improvement to the IS and digital divide evaluation techniques by including measures of the quality of ICT usage to get a more accurate and profound reflection of international inequalities in the efficiency of ICT use.

ICT Usage Index, constructed using data from the EU "i2010 benchmarking framework", jointly with the Networked Readiness Index, formed the new integrated IS and digital divide measure, which was employed to assess the evenness of IS development in the EU and the scope of the digital divide among its member states. Comparing "quantitative" (Networked Readiness Index) and "qualitative" (ICT Usage Index) levels of IS development and suggesting corresponding areas and actions for improved policy-making in the IS sphere.

Among the existing measurement tools, our integrated framework incorporates both "quantitative" and "qualitative" indicators of IS development. The suggested framework not only gives a profound estimate of the level of IS development in the EU member states and assesses the scope (and, in its perspective, the dynamics) of the digital divide between them. It also helps define links between state policies of IS building and actual levels of ICT implementation, and propose actions for improvement. Moreover, the framework can be further applied by other countries that are developing their benchmarking frameworks on the basis of Core ICT Indicators of the UN Partnership on Measuring ICT for Development.

As for weaknesses, we admit that our framework is limited to the EU member states, given that data for ICT Usage Index calculation is only collected in the EU. We also realise that our framework may need to be improved according to the newly adopted "Benchmarking Digital Europe 2011-2015" framework when data on this framework is available. As for other countries, our recommendation would be to collect similar statistical data and calculate national ICT Usage Indices, This will contribute to the global initiative of IS measurement and development.

Given the importance of IS measurement tools for policy-making purposes, future research should continue our focus on incorporating the newly-emerging indicators of ICT usage, and also over time conduct analysis to determine trends and changes in IS and digital divide development.

Also, measuring social and economic impacts of ICT usage is another challenge of the IS sphere. The development of empirical models, identifying such impacts, is an important area of exploration for scientists and policy-makers.

\section{Appendix A}

This appendix presents details on the statistical processes for constructing the ICT Usage Index.

Based on the EU "i2010 benchmarking framework", the following 44 indicators were selected on the criteria of disclosing various qualitative characteristics of ICT usage (see Table A.1). The division of indicators into groups and the group headings are maintained as in the EU "i2010 benchmarking framework".

Table A.1

The set of indicators, representing qualitative characteristics of ICT usage.

Internet usage

1. \% population who are regular internet users (using the internet at least once a week)

2. \% population who are frequent internet users (using the internet every day or almost every day)

3. \% population who have never used the internet

Take up of internet services (as \% of population)

4. Sending emails

5. Looking for information about goods and services

6. Uploading self-created content

7. Ordering goods or services, over the internet, for private use

8. Reading online newspapers/magazines

9. Selling goods and services (e.g. via auctions)

10. Internet banking

11. Downloading computer or video games or their updates

12. Downloading/listening to/watching music and/or films

13. Paying for online audiovisual contents

14. Listening to the web radio/watching web tv

15. Seeking health information on injury, disease or nutrition

16. Looking for a job or sending a job application

17. Doing an online course

18. Seeking information with the purpose of learning

e-business: \% of enterprises

19. Using applications for integrating internal business processes (all enterprises)

20. Using applications for integrating internal business processes (large enterprises)

21. Using applications for employees to access human resources services

22. Exchanging automatically business documents with customers/suppliers

23. Sending/receiving e-invoices

24. Sharing information electronically with customers/suppliers on supply chain management

25. Using analytical customer relation management

e-commerce

26. e-commerce as \% of total turnover of enterprises

27. \% enterprises selling online

28. \% enterprises purchasing online

e-government

29. \% basic public services for citizens fully available online

30. \% basic public services for enterprises fully available online

31. \% of population using e-government services

32. \% of population using e-government services for returning filled in forms

33. \% of enterprises using e-government services

34. \% of enterprises using e-government services for returning filled in forms

35. Of which to submit a proposal in a public electronic tender system (eprocurement)

Broadband

36. Total DSL coverage (as \% of total population)

37. DSL coverage in rural areas (as \% of total population)

38. Broadband penetration (as \% of population)

39. Speed-\% of broadband subscriptions above 2 Mbps

40. \% of households with an internet connection

41. \% of households with a broadband connection

42. \% of enterprises with a (fixed) broadband access

43. \% of individuals using a mobile phone via UMTS (3G) to access the internet

44. \% of individuals using a laptop via wireless connection away from home/work to access the internet 
Principal components analysis was carried out to analyse the underlying nature of the data, to reveal how different indicators are associated and change in relation to each other, and to identify the most important indicators and those, which are statistically similar or insignificant.

Principal components analysis was performed for internet usage, take up of internet services, e-business, e-commerce, e-government and broadband using the StatSoft STATISTICA 6.0 programme package.

Principal components analysis involves examination of the correlation matrix of the variables and the extraction of principal components, which explain maximum variability of the data set. The results of PCA are discussed in terms of three main features: eigenvalue (represents the amount of variance accounted for by a component); the percent of variance explained by each component (components with high eigenvalues and explaining maximum variance are considered important and are retained); and component loadings (correlations between the original variables and the component, with higher loadings making the variable representative of the component).

The results of the conducted principal components analysis are presented in Table A.2.

In case of internet usage indicators, one component that explained $98 \%$ of the variability of the data set was retained (explained by 3 indicators: see Table A.3); in case of take-up of internet-services, two components were retained (explained by 12 indicators: see Table A.3); in case of e-business, two components were retained (explained by 3 indicators: see Table A.3); in case of e-commerce, one component was retained (explained by 3 indicators: see Table A.3); in case of e-government, three components were retained (explained by 6 indicators: see Table A.3); in case of broadband, two components were retained (explained by 8 indicators: see Table A.3).

Table A.3 presents the final set of indicators (variables) retained and the corresponding component loadings.

Table A.2

Results of the principal components analysis.

\begin{tabular}{|c|c|c|c|}
\hline & Eigenvalue & Share of total variance explained (\%) & Cumulative share of variance explained (\%) \\
\hline \multicolumn{4}{|c|}{ Internet usage indicators } \\
\hline Component 1 & 2.944037 & 98.13457 & 98.1346 \\
\hline Component 2 & 0.050912 & 1.69707 & 99.8316 \\
\hline Component 3 & 0.005051 & 0.16836 & 100.0000 \\
\hline \multicolumn{4}{|c|}{ Take up of internet services indicators } \\
\hline Component 1 & 10.36520 & 69.10131 & 69.1013 \\
\hline Component 2 & 1.19980 & 7.99865 & 77.1000 \\
\hline Component 3 & 0.93232 & 6.21545 & $83.3154 \mid$ \\
\hline Component 4 & 0.56772 & 3.78479 & 87.1002 \\
\hline Component 5 & 0.45130 & 3.00868 & 90.1089 \\
\hline Component 6 & 0.37420 & 2.49464 & 92.6035 \\
\hline Component 7 & 0.27103 & 1.80687 & 94.4104 \\
\hline Component 8 & 0.24472 & 1.63143 & 96.0418 \\
\hline Component 9 & 0.18248 & 1.21656 & 97.2584 \\
\hline Component 10 & 0.16733 & 1.11553 & 98.3739 \\
\hline Component 11 & 0.08398 & 0.55985 & 98.9338 \\
\hline Component 12 & 0.06653 & 0.44355 & 99.3773 \\
\hline Component 13 & 0.05601 & 0.37341 & 99.7507 \\
\hline Component 14 & 0.02650 & 0.17669 & 99.9274 \\
\hline Component 15 & 0.01089 & 0.07258 & 100.0000 \\
\hline \multicolumn{4}{|c|}{ e-business indicators } \\
\hline Component 1 & 3.392415 & 48.46308 & 48.4631 \\
\hline Component 2 & 1.569066 & 22.41523 & 70.8783 \\
\hline Component 3 & 0.826682 & 11.80974 & 82.6880 \\
\hline Component 4 & 0.607126 & 8.67323 & 91.3613 \\
\hline Component 5 & 0.304727 & 4.35324 & 95.7145 \\
\hline Component 6 & 0.219865 & 3.14093 & 98.8554 \\
\hline Component 7 & 0.080119 & 1.14455 & 100.0000 \\
\hline \multicolumn{4}{|c|}{ e-commerce indicators } \\
\hline Component 1 & 2.471440 & 82.38133 & 82.3813 \\
\hline Component 2 & 0.423523 & 14.11744 & 96.4988 \\
\hline Component 3 & 0.105037 & 3.50123 & 100.0000 \\
\hline \multicolumn{4}{|c|}{ e-government indicators } \\
\hline Component 1 & 3.396168 & 48.51669 & 48.5167 \\
\hline Component 2 & 1.316898 & 18.81282 & 67.3295 \\
\hline Component 3 & 0.958256 & 13.68937 & 81.0189 \\
\hline Component 4 & 0.605329 & 8.64755 & 89.6664 \\
\hline Component 5 & 0.395047 & 5.64353 & 95.3100 \\
\hline Component 6 & 0.224741 & 3.21059 & 98.5206 \\
\hline Component 7 & 0.103561 & 1.47944 & 100.0000 \\
\hline \multicolumn{4}{|c|}{ Broadband indicators } \\
\hline Component 1 & 5.554431 & 61.71590 & 61.7159 \\
\hline Component 2 & 1.111593 & 12.35103 & 74.0669 \\
\hline Component 3 & 0.852817 & 9.47575 & 83.5427 \\
\hline Component 4 & 0.531218 & 5.90242 & 89.4451 \\
\hline Component 5 & 0.320725 & 3.56361 & 93.0087 \\
\hline Component 6 & 0.252822 & 2.80913 & 95.8179 \\
\hline Component 7 & 0.229401 & 2.54890 & 98.3668 \\
\hline Component 8 & 0.116384 & 1.29316 & 99.6599 \\
\hline Component 9 & 0.030608 & 0.34009 & 100.0000 \\
\hline
\end{tabular}


Table A.3

Results of the principal components analysis: variables retained and the component loadings.

\begin{tabular}{|c|c|c|}
\hline & Variables & $\begin{array}{l}\text { Component } \\
\text { loadings }\end{array}$ \\
\hline \multicolumn{3}{|c|}{ Internet usage indicators } \\
\hline 1. & $\begin{array}{l}\text { \% population who are regular internet users (using the internet } \\
\text { at least once a week) }\end{array}$ & -0.998025 \\
\hline 2. & $\begin{array}{l}\text { \% population who are frequent internet users (using the } \\
\text { internet every day or almost every day) }\end{array}$ & -0.984972 \\
\hline 3. & $\%$ population who have never used the internet & 0.988844 \\
\hline \multicolumn{3}{|c|}{ Take-up of internet-services indicators (as \% of population) } \\
\hline & Sending emails & -0.94117 \\
\hline & Looking for information about goods and services & -0.96681 \\
\hline & Uploading self-created content & -0.72954 \\
\hline & Ordering goods or services, over the internet, for private use & -0.88487 \\
\hline & Reading online newspapers/magazines & -0.81534 \\
\hline & Selling goods and services (e.g. via auctions) & -0.79445 \\
\hline & Internet banking & -0.94034 \\
\hline & Downloading/listening to/watching music and/or films & -0.88694 \\
\hline & Paying for online audiovisual contents & -0.83400 \\
\hline & Listening to the web radio/watching web tv & -0.90843 \\
\hline & Seeking health information on injury, disease or nutrition & -0.90224 \\
\hline \multicolumn{3}{|c|}{ e-business indicators: \% of enterprises } \\
\hline & $\begin{array}{l}\text { Using applications for integrating internal business processes } \\
\text { (all enterprises) }\end{array}$ & 0.814888 \\
\hline 17. & $\begin{array}{l}\text { Using applications for employees to access human resources } \\
\text { services }\end{array}$ & 0.763385 \\
\hline 18. & $\begin{array}{l}\text { Exchanging automatically business documents with customers/ } \\
\text { suppliers }\end{array}$ & 0.761143 \\
\hline \multicolumn{3}{|c|}{ e-commerce indicators } \\
\hline & e-commerce as \% of total turnover of enterprises & -0.837782 \\
\hline & \% enterprises selling online & -0.953853 \\
\hline & $\%$ enterprises purchasing online & -0.927214 \\
\hline \multicolumn{3}{|c|}{ e-government indicators } \\
\hline 22. & \% basic public services for enterprises fully available online & -0.761162 \\
\hline 23. & $\%$ of population using e-government services & 0.859956 \\
\hline 24. & $\begin{array}{l}\% \text { of population using e-government services for returning filled } \\
\text { in forms }\end{array}$ & 0.858238 \\
\hline 25. & $\%$ of enterprises using e-government services & 0.763945 \\
\hline 26. & $\begin{array}{l}\% \text { of enterprises using e-government services for returning } \\
\text { filled in forms }\end{array}$ & 0.816723 \\
\hline 27. & $\begin{array}{l}\text { of which to submit a proposal in a public electronic tender } \\
\text { system (e-procurement) }\end{array}$ & 0.845664 \\
\hline \multicolumn{3}{|c|}{ Broadband indicators } \\
\hline 28 & Total DSL coverage (as \% of total population) & -0.752187 \\
\hline 29. & DSL coverage in rural areas (as \% of total population) & -0.849110 \\
\hline 30. & Broadband penetration (as \% of population) & -0.897180 \\
\hline 31. & Speed-\% of broadband subscriptions above 2 Mbps & 0.838359 \\
\hline 32. & $\%$ of households with an internet connection & -0.913558 \\
\hline 33. & $\%$ of households with a broadband connection & -0.916866 \\
\hline 34. & $\%$ of enterprises with a (fixed) broadband access & -0.791480 \\
\hline 35. & $\begin{array}{l}\% \text { of individuals using a laptop via wireless connection away } \\
\text { from home/work to access the internet }\end{array}$ & -0.822666 \\
\hline
\end{tabular}

Thuswise, the initial set of 44 indicators (presented in Table A.1) was reduced to a set of 35 indicators (presented in Table A.3) as a result of the PCA conducted. Herein the selected indicators carry the same statistical meaning as the initial set of indicators.

The obtained set of 35 indicators was further used to develop an ICT Usage Index. The hard data on the selected indicators was accessed from the Europe's Digital Competitiveness Report (European_Commission, 2009a, 2009b). Proceeding on the premise, that ICT Usage Index is further considered in conjunction with the Networked Readiness Index, NRI methodology for index computation was used in case of ICT Usage Index to ensure compatibility of results.

The hard data on the indicators were normalised on a 1-to-7 scale (7 is the best possible value) using the standard NRI normalisation formula in order to have the same unit of measurement and align them with the NRI indicator values.
The standard NRI normalisation formula for converting hard data is the following:

$6 \rightarrow \mathrm{x}\left(\frac{\text { country.score-sample.minimum }}{\text { sample.maximum-sample.minimum }}\right)+1$.

The sample minimum and sample maximum are, respectively, the lowest and the highest country scores in the sample of economies covered by the ICT Usage Index. For those variables for which a higher value indicates a worse outcome (e.g. \% of population who have never used the internet), we followed the NRI methodology by relying on a normalisation formula that, in addition to converting the values to a 1-to-7 scale, reverses it, so that 1 and 7 still correspond to the worst and the best possible outcomes, respectively:

$\rightarrow \rightarrow 6 \times\left(\frac{\text { country.score-sample.minimum }}{\text { sample.maximum-sample.minimum }}\right)+1$.

After the data had been normalised and rescaled to identical ranges (1-to-7), ICT Usage sub index values were calculated. Following the NRI computation methodology, which is based on successive aggregations of scores (using equal weights) from the variables level (the lowest level) to the overall NRI score (the highest level), ICT Usage subindex values were computed by taking the simple average (using equal weights) of the normalised indicator values.

The final ICT Usage Index value was then computed by taking the simple average (using equal weights) of the sub index values.

Grouping of countries according to their ICT Usage Index values was performed using range as a grouping measure. The range was computed as the difference between the highest and the lowest values in the data set:

$\mathrm{R}=$ sample $_{\max }-$ sample $_{\min }$.

The sample maximum and sample minimum are, respectively, ICT Usage Index scores of the best (Norway) and the worst (Romania) performing countries.

The group size was then calculated by dividing the range by the chosen number of groups (3 groups).

Group size $=\mathrm{R} / 3$.

The list of groups and their cutoffs were finally computed by adding the group size value to the lowest value in the data set (the 1st groupcountries with low levels of ICT usage, index values ranging from 1.0311 to 2.3274), and by consequentially increasing the received value by the group size value, until the end value is larger or equal to the last value in the dataset (2nd group-countries with medium levels of ICT usage, index values ranging from 2.3274 to 3.6236 ; and 3rd group-countries with high levels of ICT usage, index values ranging from 3.6236 to 4.9199).

European_Commission (2009a, 2009b). Europe's Digital Competitiveness Report (Vol. i2010-ICT Country Profiles). Brussels: European Commission.

\section{References}

Bhatia, S. (2001). e-ASEAN readiness assessment. from. http://www.itu.int/asean2001/ documents/pdf/Document-28.pdf

Bridges.org (2005). E-readiness assessment tools comparison 2005. from. http://www. bridges.org/e_readiness_assessment

Bui, Tung X. I. M. S. Jones, Wayne, \& Naklada, Saisamorn (2002). E-commerce readiness in East Asian APEC Economies. A precursor to determine human resource development (HRD) requirements and capacity building, 98.

Campbell, D. (2001). Can the digital divide be contained? International Labour Review 140(2), 119.

Choucri, N., Maugis, V., Madnick, S., \& Siegel, M. (2003). Global e-readiness-for what? Paper 177. : Group for Globalization of e-Business, Center for eBusiness at MIT, Sloan School of Management. 
Computer_Systems_Policy_Project (2002). The CSPP guide to global electronic commerce readiness. from. http://www.cspp.org/projects/cspp_gec/cspp.html

Devins, D., Darlow, A., \& Webber, D. (2008). Beyond 'access': Internet use and take-up of online services by adults living in disadvantaged areas in England. Local Economy, 23(1), 47-57. http://dx.doi.org/10.1080/02690940801906734.

Dewan, S., \& Frederick, J. R. (2005). The digital divide: current and future research directions. Journal of the Association for Information Systems, 6(12), 298-336.

Duquaine-Watson, J. M. (2006). Understanding and combating the digital divide for single mother college students: A case study. Equal Opportunities International, 25(7), 562-576.

Economist_Intelligence_Unit_IBM_Institute_for_Business_Value (2010). Digital economy rankings 2010: Economist intelligence unit. : IBM Institute for Business Value.

European_Commission (2009a). Benchmarking digital Europe 2011-2015: A conceptual framework i2010_high_level_group. : The European Commission.

European_Commission (2009b). Europe's Digital Competitiveness Report (vol. i2010-ICT country profiles). Brussels: European Commission.

European_Commission (2010). i2010-a European information society for growth and employment. from. http://ec.europa.eu/information_society/eeurope/i2010/ benchmarking/index_en.htm

Ferro, E., Helbig, N. C., \& Gil-Garcia, J. R. (2011). The role of IT literacy in defining digital divide policy needs. Government Information Quarterly, 28(1), 3-10. http: //dx.doi.org/10.1016/j.giq.2010.05.007.

Gang, P. (2010). Critical mass, diffusion channels, and digital divide. Journal of Computer Information Systems, 50(3), 63-71.

Goldfarb, A., \& Prince, J. (2008). Internet adoption and usage patterns are different: Implications for the digital divide. Information Economics E Policy, 20(1), 2-15. http://dx.doi.org/10.1016/j.infoecopol.2007.05.001.

Hanafizadeh, P., Hanafizadeh, M. R., \& Khodabakhshi, M. (2009). Taxonomy of e-readiness assessment measures. International Journal of Information Management, 29(3), 189-195. http://dx.doi.org/10.1016/j.ijinfomgt.2008.06.002.

Harvard Center for International Development (nd). I. What are the benefits of the networked world for developing countries? from. http://cyber.law.harvard.edu/ readinessguide/foreword.html

ITU (2010). Measuring the information society 2010. Geneva: ITU.

ITU (2012). Measuring the information society 2012, executive summary. Geneva: ITU.

Jackson, L. A., Samona, R., Moomaw, J., Ramsay, L., Murray, C., Smith, A., et al. (2007). What children do on the internet: Domains visited and their relationship to socio-demographic characteristics and academic performance. CyberPsychology $\mathcal{E}$ Behavior, 10(2), 182-190. http://dx.doi.org/10.1089/cpb.2006.9970.

Jackson, L. A., Von Eye, A., Biocca, F., Barbatsis, G., Yong, Z., \& Fitzgerald, H. (2005). Instructional set and internet use by low-income adults. CyberPsychology \&' Behavior, 8(5), 465-472. http://dx.doi.org/10.1089/cpb.2005.8.465.

Karvalics, L. Z. (2007). Information society-what is it exactly? (The meaning, history and conceptual framework of an expression). In R. Pintér (Ed.), Information society from theory to political practice. Budapest: Library of Congress Cataloging-in-Publication Data (Retrieved from http://www.ittk.hu/netis/doc/ISCB_eng/02_ZKL_final.pdf)

Lu, M. -t (2001). Digital divide in developing countries. Journal of Global Information Technology Management, 4(3), 1-4.

McConnell_International (2000). Risk E-business: Seizing the opportunity of global E-readiness.

McNair, S. (2000). The emerging policy agenda schooling for tomorrow. Vol. learning to bridge the digital divide. : OECD, 9-19.

Menou, M., \& Taylor, R. (2006). A "grand challenge": Measuring information societies. Information Society, 22(5), 261-267. http://dx.doi.org/10.1080/01972240600903904.

OECD (1999). A global action plan for economic commerce: Prepared by business with recommendations for governments. OECD digital economy papers (pp. 44).
Partnership_on_Measuring-ICT_for_Development (2010). Core ICT indicators, 2010. Geneva: International Telecommunication Union.

Rodríguez, F., \& Wilson, E. J., III (2000). Are poor countries losing the information revolution? Working paper. : InfoDev, World Bank (Retrieved from http://www.cidcm.umd. edu/library/papers/ewilson/apxc.pdf)

Rue, F. L. (2011). Report of the special rapporteur on the promotion and protection of the right to freedom of opinion and expression: United Nations General Assembly. : Human Rights Council.

Sachs, J. (2000). Today's world is divided not by ideology but by technology. The Economist, 26, 81-83.

SIBIS (2001). Definitions statistical indicators benchmarking the information society-work package 1: eEurope benchmarking framework.

Souter, D. (2010). Towards inclusive knowledge societies. A review of UNESCO's action in implementing the WSIS outcomes. : UNESCO, Communication and Information Sector.

The World_Bank (2009). KEI and KI indexes (KAM 2009). from. http://info.worldbank.org/ etools $/ \mathrm{kam} 2 / \mathrm{KAM} \_$page5.asp $? \mathrm{tid}=0 \&$ year $=2002 \&$ sortby $=$ KEI\&sortorder $=$ ASC\&weighted $=$ Y\&cid $1=\mathrm{S}$

Wikipedia (2011). Information society. from. http://en.wikipedia.org/wiki/ Information_society

World_Economic_Forum_INSEAD (2009). The Global Information Technology Report 2008-2009. In I. M. S. Dutta (Ed.), Mobility in a networked world (pp. 387). Geneva: World Economic Forum, INSEAD.

World_Economic_Forum_INSEAD (2011). The Global Information Technology Report 2010-2011. In I. M. Soumitra Dutta (Ed.), Transformations 2.0. Geneva: World Economic Forum, INSEAD.

WSIS (2003a). World Summit on the Information Society: Declaration of Principles. from. http://www.itu.int/wsis/docs/geneva/official/dop.html

WSIS (2003b). World Summit on the Information Society: Plan of Action. from. http://www.itu.int/wsis/docs/geneva/official/poa.htm

WSIS (2005). World Summit on the Information Society: Tunis Agenda for the Information Society. from. http://www.itu.int/wsis/docs2/tunis/off/6rev1.html

WSIS (2008). World Summit on the Information Society: Basic Information. from. http://www.itu.int/wsis/basic/why.html

Bjarne Rerup Schlichter is an Associate Professor of Information Systems at the Department of Business Administration, Aarhus University (Denmark) and a visiting professor at the Ukrainian-Dutch Faculty of Ternopil National Economic University (Ukraine). He holds a master's degree in Computer Science and an advanced diploma in Business Administration and Organization achieved in 1990. He received his PhD in Information Systems from Aarhus School of Business. He entered academia in 2002 after a career in various consulting companies. Among others he was a Government Industry Leader for PwCDenmark from 1998 to 2000 and Head of the International IT-Consultancy at Rambøll Management from 2000-2002. He was appointed as an external expert in information systems and technologies by the Danish High Court and by the Danish Arbitrage. His major research interests include aspects of conflict, including trust, during implementation of information systems.

Lesya Danylchenko is a lecturer at the Department of International Management and Marketing, Ternopil National Economic University. She holds a master's degree in Management of Foreign Economic Activity (2007). She received her PhD in International Economics in Ternopil National Economic University, Ukraine, in 2011. Her major research interests include aspects of global IS development, including digital divide and ICT usage. 